\title{
Peningkatan Aktivitas dan Prestasi Belajar Matematika Melalui Pendekatan Realistic Mathematics Education (RME) Berbantuan Media Manipulatif Siswa Kelas I Sekolah Dasar
}

\author{
Tri Wisudawati \\ SD Negeri 1 Karangkobar \\ email: triwisudawati38@gmail.com
}

\begin{abstract}
This study aims to describe learning activities and achievements using the realistic mathematics education (RME) approach is assisted by manipulative media. This research technique used classroom action research (PTK), which was conducted in two cycles and used the research design of Kemmis \& McTaggart. The data collection techniques used were observation, tests, and documentation. The collected data were analyzed using quantitative descriptive analysis techniques. The results of research conducted in class IA SD Negeri 1 Karangkobar show that learning using the realistic mathematics education (RME) approach is assisted by manipulative media works well. The result of the learning activity ability from pre-cycle is only 1 student or $3.3 \%$ to 24 students or $80 \%$ at the end of cycle II. In addition, there was also an increase in learning achievement from a mean score of 58.23 and $23.3 \%$ completeness in pre-cycle to 78.6 and $83.3 \%$ completeness at the end of cycle II. Thus the use of a realistic mathematics education (RME) approach is assisted by manipulative media will increase the ability of learning activities and student achievement in grade 1A SD Negeri 1 Karangkobar.
\end{abstract}

Keywords: Action research, Learning activities, Learning achievement, Realistic Mathematics Education

Abstrak. Penelitian ini bertujuan untuk mendeskripsikan aktivitas dan prestasi belajar menggunakan pendekatan realistic mathematics education (RME) berbantuan media manipulatif. Teknik penelitian ini menggunakan penelitian tindakan kelas (PTK), yang dilakukan dalam dua siklus dan menggunakan desain penelitian Kemmis \& McTaggart. Teknik pengumpulan data yang digunakan yaitu observasi, tes, dan dokumentasi. Data yang telah terkumpul dianalisis dengan menggunakan teknik analisis deskriptif kuantitatif. Hasil penelitian yang dilakukan di kelas IA SD Negeri 1 Karangkobar menunjukkan bahwa pembelajaran dengan pendekatan realistic mathematics education (RME) berbantuan media manipulatif berlangsung dengan baik. Hasil kemampuan aktivitas pembelajaran dari prasiklus hanya 1 siswa atau 3,3\% menjadi 24 siswa atau $80 \%$ pada akhir siklus II. Selain itu juga terjadi peningkatan prestasi belajar dari nilai rerata 58,23 dan ketuntasan 23,3\% pada prasiklus menjadi 78,6 dan ketuntasan 83,3\% pada akhir siklus II. Dengan demikian penggunaan pendekatan realistic mathematics education (RME) berbantuan media manipulatif membawa peningkatan kemampuan aktivitas pembelajaran dan prestasi belajar siswa kelas 1A SD Negeri 1 Karangkobar.

Kata Kunci: Aktivitas belajar, Prestasi belajar, PTK, Realistic Mathematics Education 
Jurnal Riset Pendidikan Dasar

Volume 2 Nomor 2, September 2021; DOI 10.30595/jrpd.v2i2.9917

\section{PENDAHULUAN}

Matematika adalah satu dari sekian banyak pelajaran yang tercakup dalam kurikulum 2013 dan menduduki posisi yang penting, bahkan begitu besar penekanannya pada anak untuk berhasil dalam pembelajaran. Pembelajaran matematika sangat bermanfaat bagi siswa karena dapat membekali siswa kemampuan berpikir logis, analitis, sistematis, kritis, kreatif, mampu bekerjasama dan mampu mengaplikasikannya dalam kehidupan sehari-hari. Kompetensi tersebut diperlukan agar siswa dapat memperoleh, mengelola, dan memanfaatkan informasi untuk memecahkan masalah dan bertahan hidup dalam keadaan yang selalu berubah, tidak pasti, dan kompetitif di masa yang akan datang. Permendikbud nomor 54 tahun 2013 tentang Standar Kompetensi Lulusan SD/MI pada aspek pengetahuan diharapkan siswa memiliki pengetahuan faktual dan konseptual berdasarkan rasa ingin tahunya tentang ilmu pengetahuan, teknologi, seni, dan budaya dalam wawasan kemanusiaan, kebangsaan, kenegaraan, dan peradaban terkait fenomena dan kejadian di lingkungan rumah, sekolah, dan tempat bermain. Begitu pentingnya pembelajaran matematika untuk siswa sekolah dasar, maka perlu diimbangi dengan proses pembelajaran matematika yang optimal untuk siswa di kelas.

Berdasarkan observasi pembelajaran matematika di kelas IA SD Negeri 1 Karangkobar Tahun Pelajaran 2019/2020 menunjukkan hasil yang perlu ditingkatkan. Pada aspek kemampuan proses pembelajaran terlihat kemampuan aktivitas pembelajaran siswa masih rendah. Dari 30 siswa, satu siswa memiliki kemampuan aktivitas pembelajaran berkriteria sangat baik, enam siswa memiliki kemampuan aktivitas pembelajaran berkriteria baik, dua puluh satu siswa berkriteria cukup, dan dua siswa berkriteria kurang. Demikian halnya pada aspek prestasi belajar matematika. Berdasarkan hasil analisis dokumen ulangan harian matematika. Kriteria Ketuntasan Minimal (KKM) muatan pelajaran matematika pada kelas ini adalah 70, dengan ketuntasan belajar baru mencapai 23,3\% dan nilai rata-rata 58,23. Dari data tersebut dapat ditarik kesimpulan bahwa hanya ada 7 orang siswa yang telah memenuhi standar ketuntasan minimal, sementara 23 siswa lainnya belum tuntas.

Penyebab rendahnya aktivitas dan prestasi belajar matematika kelas ini antara lain: pembelajaran lebih didominasi model ceramah dan lebih bersifat tekstual, kegiatan pembelajaran masih kurang mampu merangsang siswa untuk terlibat secara aktif dalam proses belajar-mengajar. Siswa masih pasif dan kurang bergairah dalam mempelajari matematika, karena siswa hanya dituntut untuk menghafal materi yang diberikan oleh guru, tanpa adanya tuntutan mencari, mengembangkan pengetahuan, dan pemahamannya pada hal-hal lain guna menunjang dan memantapkan pemahaman mereka mengenai materi matematika.

Selain permasalahan tersebut, permasalahan lainnya yaitu pembelajaran masih berpusat pada guru, guru juga belum menggunakan media pembelajaran, hanya terpaku pada konsep pembelajaran konvensional, hanya mengejar target terselesaikannya materi pelajaran, pembelajaran hanya mengandalkan pada penjelasan guru atau mengerjakan tugas di 
LKS, sehingga siswa mengalami kesulitan untuk memahami materi matematika. Berdasarkan uraian sebelumnya, dapat diambil sebuah kesimpulan bahwa selama kegiatan pembelajaran berlangsung, seharusnya siswalah yang dituntut untuk aktif sehingga guru bukan merupakan pemeran utama pembelajaran. Satu hal yang perlu digarisbawahi di sini, bahwa guru bukan sebagai pusat pembelajaran, melainkan sebagai pemandu, motivator, dan fasilitator.

Untuk meningkatkan prestasi belajar matematika siswa dan penguasaan siswa terhadap konsep dasar matematika serta untuk meningkatkan aktivitas siswa, guru diharapkan mampu berkreasi dengan menerapkan model ataupun pendekatan dalam pembelajaran matematika yang cocok. Model atau pendekatan ini haruslah sesuai dengan materi yang akan diajarkan serta dapat mengoptimalkan suasana belajar. Salah satu pendekatan yang membawa alam pikiran siswa ke dalam pembelajaran dan melibatkan siswa secara aktif adalah pendekatan matematika realistik atau terkenal dengan nama Realistic Mathematic Education (RME). Pendekatan RME di Indonesia dikenal dengan istilah Pendidikan Matematika Realistik Indonesia (PMRI).

Pendekatan Realistic Mathematics Education (RME) digunakan sebagai titik awal untuk pengembangan ide dan konsep matematika. Penjelasan lebih lanjut bahwa pembelajaran matematika realistis ini berangkat dari kehidupan anak, yang dapat dengan mudah dipahami oleh anak, nyata, dan terjangkau oleh imajinasinya, dan dapat dibayangkan sehingga mudah baginya untuk mencari kemungkinan penyelesaiannya dengan menggunakan kemampuan matematis yang telah dimiliki (Hadi, 2005:19). Menurut Aisyah (2007), Realistic Mathematics Education (RME) merupakan suatu pendekatan belajar matematika yang dikembangkan untuk mendekatkan matematika kepada siswa. Masalah-masalah nyata dari kehidupan sehari-hari yang dimunculkan sebagai titik awal pembelajaran matematika. Penggunaan masalah realistis ini bertujuan untuk menunjukkan bahwa matematika sebenarnya dekat dengan kehidupan sehari-hari siswa. Pendekatan Realistic Mathematics Education (RME) tepat diterapkan dalam mengajarkan konsepkonsep dasar dan diharapkan mampu meningkatkan aktivitas dan kemampuan berfikir siswa yang akhirnya bermuara pada meningkatnya prestasi belajar siswa.

Pada pelaksanaannya sintaks pendekatan RME yang digunakan yaitu (1) Menyajikan masalah kontekstual, aktivitasnya guru memberikan masalah kontekstual dan mengarahkan siswa untuk memahami masalah tersebut, (2) Menjelaskan masalah kontekstual, aktivitasnya siswa diarahkan untuk mengumpulkan informasi dari masalah kontekstual, (3) Menyelesaikan masalah kontektual, aktivitasnya guru memimpin diskusi, memberikan pertanyaan, dan mengarahkan siswa mencapai tujuan pembelajaran, (4) Membandingkan dan mendiskusikan jawaban (5) Menyimpulkan, aktivitasnya siswa menghubungkan materi yang sedang dipelajari dengan materi lain dalam matematika.

Pemilihan pendekatan pembelajaran tertentu akan mempengaruhi media apa yang akan digunakan, untuk mengurangi verbalisme guru dan abstraksi peserta didik dalam pelaksanaan Pendekatan Realistic 
Jurnal Riset Pendidikan Dasar

Volume 2 Nomor 2, September 2021; DOI 10.30595/jrpd.v2i2.9917

Mathematics Education (RME) dibutuhkan media yang cocok dengan jenis pembelajaranya. Memilih dan menggunakan media harus sesuai dengan tujuan, materi, metode, evaluasi dan yang utama dapat memperlancar pencapaian tujuan serta menarik minat siswa. Menurut Arsyad (2013:19), salah satu fungsi utama media pembelajaran adalah sebagai alat bantu mengajar yang mempengaruhi iklim, kondisi, dan lingkungan belajar yang ditata dan diciptakan oleh guru. Media manipulatif matematika didefinisikan sebagai materi atau benda dari dunia nyata untuk menunjukkan konsep matematika. Media tersebut harus dapat diamati dan disentuh oleh indra siswa. Dengan berbantuan media manipulatif harapannya dapat memperlancar pemahaman dan memperkuat ingatan peserta didik.

Rumusan masalah dalam penelitian ini adalah bagaimanakah penerapan pendekatan realistic mathematics education (RME) berbantuan media manipulatif untuk meningkatkan aktivitas dan prestasi belajar matematika pada siswa kelas IA SDN 1 Karangkobar Kecamatan Karangkobar Semester 2 Tahun Pelajaran 2019/2020? Tujuan diadakannya penelitian ini adalah untuk mengetahui peningkatan aktivitas dan prestasi belajar matematika setelah diterapkan pendekatan realistic mathematics education (RME) berbantuan media manipulatif pada siswa kelas IA SDN 1 Karangkobar. Manfaat yang diharapkan dari penelitian ini adalah memperoleh pengetahuan baru dan inovatif dalam hal teknik pembuatan dan penggunaan media manipulatif serta memperoleh pengetahuan dan pengalaman baru dalam menggunakan pendekatan realistic mathematics education (RME).
Permasalahan yang terjadi dalam pembelajaran matematika siswa kelas IA SD Negeri 1 Karangkobar harus segera mendapatkan solusi. Oleh karena itu, peneliti berdiskusi dengan guru kelas lain dan sepakat memilih pendekatan realistic mathematics education (RME) dibantu media manipulatif untuk diterapkan dalam pembelajaran di kelas IA SD Negeri 1 Karangkobar.

\section{METODE}

Jenis penelitian yang digunakan adalah penelitian tindakan kelas (PTK). Ada empat langkah dalam PTK yang meliputi perencanaan, pelaksanaan tindakan, observasi, dan refleksi, model ini dikembangkan oleh Kemmis dan Taggart (Akbar, 2009:30). Kehadiran peneliti di kelas mutlak diperlukan karena peneliti bertindak sebagai instrumen kunci yang dalam hal ini sebagai pemberi tindakan yaitu bertindak sebagai pengajar atau guru sesuai jadwal pelajaran yang berlaku selama berlangsungnya kegiatan penelitian. Peneliti juga sebagai instrumen kunci dalam penelitian karena selain melakukan tindakan, peneliti terlibat langsung mulai dari menyusun perencanaan pembelajaran, pengumpul data dan penganalisa, serta melaporkan hasil penelitian. Pada penelitian ini dibantu teman sejawat yang bertindak sebagai observer yaitu guru kelas I B SD Negeri 1 Karangkobar Ibu Asih Wahyuning. Waktu penelitian dari mulai bulan Januari hingga Maret Tahun 2020. Subjek yang digunakan adalah siswa kelas IA dengan jumlah 30 siswa yang meliputi 15 siswa peremuan dan 15 siswa laki-laki. Teknik pengumpulan data menggunakan observasi, tes, dan dokumentasi. Teknik 
Jurnal Riset Pendidikan Dasar

Volume 2 Nomor 2, September 2021; DOI 10.30595/jrpd.v2i2.9917

analisis data menggunakan analisis deskriptif kuantitatif.

\section{HASIL DAN PEMBAHASAN}

Secara keseluruhan, penelitian mengenai penerapan pendekatan realistic mathematics education (RME) berbantuan media manipulatif untuk meningkatkan aktivitas dan prestasi belajar matematika siswa kelas IA menunjukkan adanya peningkatan aktivitas dan prestasi belajar matematika siswa. Berkat intervensi dengan penerapan pendekatan realistic mathematics education (RME) berbantuan media manipulatif maka, aktivitas pembelajaran siswa mengalami kenaikan. Hal ini disebabkan karena penerapan pendekatan realistic mathematics education (RME) berbantuan media manipulatif, kondisi siswa menjadi: 1) lebih antusias, 2) lebih aktif dan kreatif, 3) lebih berkonsetrasi, 4) lebih bersemangat. Situasi kelas menjadi: 1) lebih menyenangkan, 2) lebih kondusif, 3) lebih bervariasi dan, 4) lebih bermakna. Berikut grafik kenaikan aktivitas pembelajaran:

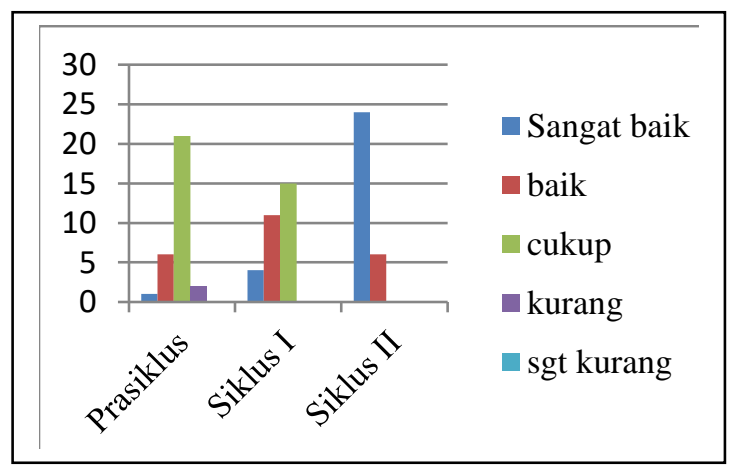

\section{Gambar 1. Kenaikan Aktivitas}

Pembelajaran Dari Prasiklus, Siklus I, dan Siklus II

Berdasarkan gambar tersebut ada kenaikan aktivitas pembelajaran yang sangat baik dari 4 siswa menjadi 24 siswa. Pada siklus II diperoleh hasil, siswa yang memiliki kemampuan aktivitas pembelajaran berkriteria sangat baik ada 24 atau $80 \%$, dan siswa yang memiliki kemampuan aktivitas pembelajaran berkriteria baik ada 6 atau 20\%. Ini berarti ada kenaikan kemampuan aktivitas pembelajaran sebanyak 20 siswa dari siklus I ada 4 siswa menjadi 24 siswa siklus II. Grafik tersebut juga menunjukan kemampuan aktivitas pembelajaran pada siklus I di mana terdapat 15 siswa berkriteria cukup yang mengalami perubahan menjadi tidak ada satupun siswa berkriteria cukup pada siklus II. Kemampuan aktivitas pembelajaran berkriteria baik pada siklus I menunjukan ada 11 siswa yang juga mengalami penurunan menjadi hanya 6 siswa pada siklus II.

Selain aktivitas pembelajaran, yang perlu mendapat perhatian lainnya adalah prestasi belajar matematika yang masih rendah, nilai rata-rata pada prasiklus baru mencapai 58,23. Kondisi ini disebabkan belum maksimalnya pengelolaan proses belajar mengajar. Melalui diskusi awal, perlu dilakukan perbaikan pembelajaran melalui pendekatan realistic mathematics education (RME) berbantuan media manipulatif. Pada awal pelaksanaan pembelajaran pendekatan realistic mathematics education (RME) berbantuan media manipulatif terlihat siswa masih malu-malu, canggung, kurang bersemangat, dan bingung dalam memerankan sesuai tugasnya, siswa juga ragu-ragu untuk menjawab pertanyaan. Pertemuan kedua dan ketiga siswa semakin percaya diri pada pembelajaran, siswa dalam menyampaikan jawaban sudah dengan suara lantang dan 
jelas serta mengangkat tangan untuk bertanya pada hal yang masih bingung, meskipun tetap ada siswa yang kurang memperhatikan penjelasan guru.

Hal-hal positif lainnya dalam pembelajaran dengan pendekatan RME yaitu siswa terlihat lebih mudah memahami dan menyelesaikan soal yang diberikan guru. Pembelajaran nampak menyenangkan dan siswa semakin antusias. Sejalan dengan pendapat Susilowati (2018:51) dengan pendekatan pembelajaran RME siswa merasa senang dan sebagian besar pula menganggap sebagai hal yang baru. Guru juga dapat melaksanakan pembelajaran matematika secara efektif. Kondisi ini sesuai dengan teori pendekatan RME, Menurut Muhsetyo dkk (2007), Realistic Mathematics Education (RME) dimaksudkan untuk memulai pembelajaran matematika dengan cara mengaitkannya dengan situasi dunia nyata disekitar siswa. Hal ini menandakan bahwa RME memiliki semangat yang sama dengan pembelajaran bermakna di mana matematika dapat disesuaikan dengan berbagai situasi yang beragam. Pendekatan RME dengan langkah-langkah yang terstruktur memfasilitasi siswa untuk menganalisis masalah, membuat rencana untuk memecahkan masalah, mengevaluasi, mengidentifikasi dan menerapkan tindakan yang diperlukan untuk memperbaiki atau kinerja yang benar, dan menilai apakah hasil yang diinginkan tercapai atau tidak, sehingga pendekatan RME dapat meningkatkan kemampuan berpikir kritis siswa (Setianingsih, 2016).

Pembelajaran pendekatan realistic mathematics education (RME) berbantuan media manipulatif juga terlihat sangat interaktif, baik guru dengan siswa maupun siswa dengan siswa lainnya. Hal ini sejalan dengan pendapat Aisyah (2007) proses pembelajaran harus interaktif. Interaksi baik antar guru dan siswa maupun siswa dengan siswa merupakan elemen yang penting dalam pembelajaran matematika. Siswa dapat berdiskusi dan bekerja sama dengan siswa lain, bertanya, dan menanggapi pertanyaan serta mengevaluasi pekerjaan mereka. Menurut Suryanto (2007) Karakteristik pendekatan RME itu sendiri antara lain: siswa merefleksikan (memikirkan kembali) apa yang telah dikerjakan dan apa yang telah dihasilkan; baik hasil kerja mandiri maupun hasil diskusi. Siswa dibantu untuk mengaitkan beberapa isi pelajaran matematika yang memang ada hubungannya. Siswa diajak mengembangkan, memperluas, atau meningkatkan hasil-hasil dari pekerjaannya agar menemukan konsep atau prinsip matematika yang lebih rumit.

Peningkatan prestasi belajar pada penelitian ini juga sejalan dengan pendapat Kartika dan Maulana (2016:43) pendekatan matematika realistik merupakan pembelajaran yang berorientasi pada aktivitas pengkonstruksian pengetahuan dengan menghubungkan antar konsep untuk memecahkan masalah yang berhubungan dengan aktivitas manusia yang berguna untuk mengembangkan pola pikir praktis, logis, kritis, dan jujur dengan menggunakan konteks dari lingkungan dalam mengajarkan konsepnya. Santrock (2012:304) yang mengatakan bahwa bergaul dengan teman sebaya membantu anak menemukan informasi dan perbandingan mengenai dunia luar keluarga. Pendapat lain juga dikemukakan oleh Indraningtias dkk (2017: 20-21) model pembelajaran Realistic Mathematic Education (RME) 
memiliki kelebihan yaitu: (1) memberikan pengertian kepada siswa tentang keterkaitan matematika dengan kehidupan sehari-hari, dan (2) memberikan pengertian kepada siswa bahwa matematika adalah suatu bidang kajian yang dikonstruksi dan dikembangkan sendiri oleh siswa tidak hanya oleh mereka yang disebut pakar dalam bidang tersebut. Berikut grafik kenaikan prestasi belajar matematika siswa kelas IA SD Negeri 1 Karangkobar.

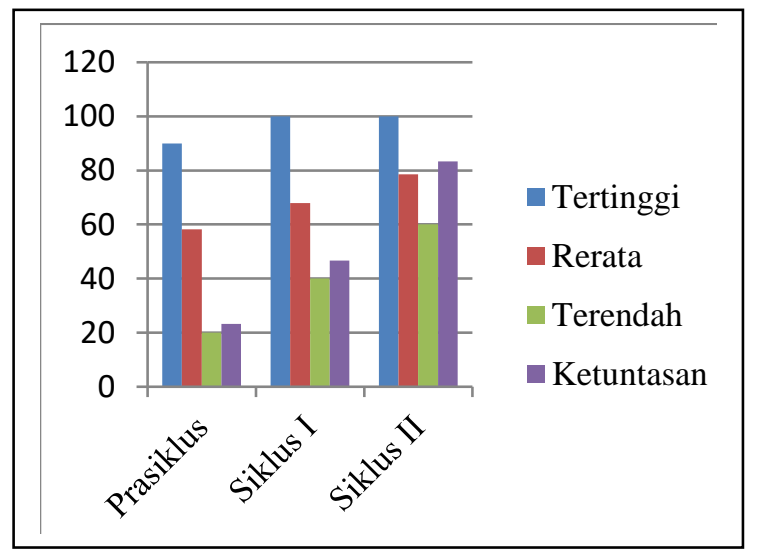

Gambar 2. Kenakan Prestasi Belajar Dari Prasiklus, Siklus I, dan Siklus II

Gambar tersebut menunjukan prestasi belajar mata pelajaran matematika yang diukur melalui tes prestasi belajar pada prasiklus rerata adalah 58,23 dengan ketuntasan belajar 23,3\%. Setelah dilakukan pembelajaran dengan menggunakan pendekatan realistic mathematics education (RME) berbantuan media manipulatif mengalami peningkatan. Pada siklus I rerata menjadi 67,9 dan ketuntasan belajar sebanyak $46,7 \%$ dari hasil refleksi, sayangnya hasil tersebut masih belum mencapai indikator keberhasilan. Dengan memperbaiki kekurangan yang ada pada siklus I yaitu dengan penjelasan langkahlangkah kancing gemerincing dengan detail dan pemberian tugas berupa pekerjaan rumah, hasil tes prestasi pada siklus II rerata menjadi 78,6 dan ketuntasan belajar menjadi $83,3 \%$.

\section{SIMPULAN}

Berdasarkan hasil analisis dan pembahasan dapat disimpulkan bahwa penerapan pendekatan realistic mathematics education (RME) berbantuan media manipulatif, dapat meningkatkan kemampuan aktivitas pembelajaran, mata pelajaran matematika siswa kelas IA SD Negeri 1 Karangkobar semester II tahun pelajaran 2019/2020 dari prasiklus hanya 1 siswa atau 3,3\% menjadi 24 siswa atau $80 \%$ pada akhir siklus II. Selain meningkatkan aktivitas, penerapan pendekatan realistic mathematics education (RME) berbantuan media manipulatif juga terbukti dapat meningkatkan prestasi belajar matematika siswa kelas IA SD Negeri 1 Karangkobar semester II tahun pelajaran 2019/2020 dari nilai rata-rata 58,23 dan ketuntasan 23,3\% pada prasiklus menjadi 78,6 dan ketuntasan $83,3 \%$ pada akhir siklus II.

\section{DAFTAR PUSTAKA}

Aisyah, Nyimas. 2007. Pengembangan Pembelajaran Matematika SD. Jakarta: Dirjen Dikti Depdiknas.

Akbar, S. 2009. Penelitian Tindakan Kelas. Malang: Cipta Media Aksara.

Arsyad, Azhar. 2013. Media Pembelajaran. Depok: PT. Raja Grafindo Persada.

Hadi, Sutarto. 2005. Pendidikan Matematika Realistik dan Implementasinya. Banjarmasin: Tulip.

Indraningtias, Aryadi, Diah Ayu, dan Wijaya. (2017). Pengembangan Perangkat 
Jurnal Riset Pendidikan Dasar

Volume 2 Nomor 2, September 2021; DOI 10.30595/jrpd.v2i2.9917

Pembelajaran Berbasis Pendekatan

Matematika Realistik Materi Bangun Ruang Sisi Datar Berorientasi Pada Kemampuan Berpikir Kritis Siswa Kelas VIII SMP. Pendidikan Matematika, 6(5), 24-36.

http://eprints.uny.ac.id/id/eprint/51614
Pembelajaran, 4(1),

44-53. https://doi.org/10.29407/pn.v4i1.12494

Suryanto. 2007. "Pendidikan Matematika Realistik Indonesia (PMRI)". Majalah PMRI Vol. V No. 1 Januari 2007, halaman $8-10$.

Kartika Fitriani, Maulana. (2016).

Meningkatkan Kemampuan

Pemahaman Dan Pemecahan Masalah

Matematis Siswa SD Kelas V Melalui

Pendekatan Matematika Realistik, Mimbar Sekolah Dasar UPI, Vol. 3(1) (2016), 40-52, (2016),

DOI: 10.17509/mimbar-sd.v3i1.2355.

Muhsetyo, Gatot dkk. 2007. Pembelajaran Matematika SD. Jakarta: Universitas Terbuka.

Permendikbud Nomor 54 tahun 2013.

Santrock, John W. (2012). Life-Span Developmen; Perkembangan Masa-Hidup Edisi Ketigabelas Jilid I. Penerjemah Benedictine Widyasinta. Jakarta: Erlangga.

Setianingsih, R. (2016). Implementasi Pendekatan Pembelajaran Matematika Realistik untuk Mengembangkan Keterampilan 4C Siswa Sekolah Dasar. Prosiding Seminar Nasional Matematika, 524536.

Susilowati, E. (2018). Peningkatan Aktivitas dan Hasil Belajar Matematika Siswa SD Melalui Model Realistic Mathematic Education (RME) Pada Siswa Kelas IV Semester I Di SD Negeri 4 Kradenan Kecamatan Kradenan Kabupaten Grobogan Tahun Pelajaran 2017/2018. PINUS: Jurnal Penelitian Inovasi 